\title{
Poola poliitiline huumor
}

\begin{abstract}
Marcin Poprawa
Teesid: Käesolevas artiklis antakse ülevaade tänapäeva Poola poliitilisest huumorist. Uurimus kirjeldab kaasaegse poliitilise huumori teoreetilisi aspekte ja võrdleb neid poliitiliste naljadega kommunistliku parteipropaganda aegadest Poola Rahvavabariigis (PRV). Uurimismaterjaliks on peamiselt poliitikute naljakad ütlemised, mida esmalt kasutati poliitilises poleemikas, kuid seejärel populariseeriti ajakirjanduses, nii et neist said lendsõnad, misjärel neid kasutati erinevates intertekstuaalsetes variantides avalikus ja kõnekeelses diskursuses.
\end{abstract}

Märksõnad: intertekstuaalsus, lendsõnad, poliitikakeel, poliitiline diskursus, poliitiline huumor, Poola

\section{Taust}

Käesolevas artiklis tuuakse välja kõige olulisemad kommunikatiivsed aspektid tänapäeva Poola poliitilises huumoris. Samuti püütakse seda nähtust teoreetiliselt kirjeldada ja võrrelda seda poliitiliste naljadega kommunistliku partei propaganda aegadest Poola Rahvavabariigis (PRV). Analüüsis tuuakse näiteid Poola poliitikute väljaütlemistest, mida kõigepealt kasutati poliitilises diskussioonis, pärast seda populariseerisid neid (nende koomilise sisu tõttu) ajakirjanikud ja seejärel omandasid need ütlused naljakate lendsõnade staatuse. Lõpptulemusena ilmusid need väljaütlemised erinevate intertekstuaalse huumori vormidena avalikus ja kõnekeelses diskursuses.

\section{Poliitiline huumor kui nähtus}

Kuigi termin "poliitiline huumor" viitab naljakatele olukordadele ja kuvanditele poliitilises sfääris, esineb see sagedamini pigem sotsiaalsuhtluses kui poliitilises diskursuses (tänapäeval peamiselt trüki- või ringhäälingumeedias 
ja internetis). Kõige sagedamini esineb poliitiline huumor naljana - lühikese verbaalse narratiivina, mis lõpeb puändiga, ${ }^{1}$ - või verbaalsete ja mitteverbaalsete satiiriliste žanritega, s.t poliitiliste kommentaaride või koomiliste sketšidega, mis naeruvääristavad riiki juhtivate poliitikute puudusi, nende otsuseid, käitumist või suhtumisi.

Poliitika on ühiskonnaelu valdkond, mis peaks kõige vähem seonduma naljaga, kuid tänapäeva kultuurilised muutused on viinud olukorrani, kus poliitikakeel jõuab laiema kuulajaskonnani, ning selles kasutatakse lihtsaid, värvikaid ja emotsionaalseid väljaütlemisi, mitte keerukat ilukõnet. Seetõttu on poliitilise diskursuse ritualiseerunud vormides (nt valimiskampaaniad, poliitilised reklaamid) kasutatavad mängulised veenmisvahendid seostatud erinevate emotsioonidega (rõõmust pahameeleni: vt Brzozowska 2009c). Emotsionaalsed vahelehüüded (Zwizschenruf), s.tjuhuslikud iroonilised kommentaarid, on mõne inimese meelest humoorikas situatsioonipõhine nali, kuid teised võivad pidada neid keelevääratusteks, mis madaldavad ametliku suhtluskultuuri taset. Selliste kommunikatiivsete vahendite kasutamine on tavaline parlamentaarsetes debattides ja ajakirjanike juhitud TV-aruteludes (vt Poprawa 2009; SzkudlarekŚmiechowicz 2011; Kloch 2006 jt). Üldiselt on uurijad seisukohal, et tänapäeva poliitiline diskursus muutub koos massimeedias populariseeritavate mallidega, seega ei peetagi imelikuks "nalja hingust" (Magdoń 1995), poliitikas kasutatava keele karnevaliseerumist (Ożóg 2004 jt) ning mängulise elemendi olemasolu valimisreklaamides ja -kampaaniates (nt satiirilised videoklipid, karikatuuridel ja fotodel põhinevad pastiššid, mida poliitikud kasutavad oponentide ründamiseks). Sellistest kommunikatsioonistrateegiatest on saanud poliitilise turunduse vahend, neid kasutatakse ametlikes debattides ning nimetatakse "poliitiliseks folklooriks" (vt Kamińska-Szmaj 2001) või "populaarseks meelelahutuseks ja rahvapäraseks veenmiseks" (Olczyk 2010). Viimasena mainitud mõiste hõlmab tervet rida kommunikatiivseid strateegiaid, mille abil püütakse poliitilise võimuvõitluse auditooriumi mõjutada, kasutades loomupäraselt naljakaid tähendusi ja konnotatsioone nii pildis kui sõnas.

Tavapäraselt peetakse nalju ja humoorikaid narratiive kõnekeelde kuuluvaiks (ja need annavad tunnistust ütleja verbaalsest võimekusest), neid ei loeta üldjuhul ametliku avaliku diskursuse osaks. Siiski on mängulised vormid (ja eriti satiir) täiendanud retoorilist stiili ja avalikke kõnesid juba antiikajast, ning neid kasutatakse sündmuste, probleemide ja inimeste teravmeelseks kommenteerimiseks (Korolko 1998). ${ }^{2}$ Poliitikud tögavad oma kõnedes oponente, kasutades sageli solvavaid avaldusi (nn invectiva oratio - vt Kamińska-Szmaj 2007) või irooniat (vt Habrajska 1994). Avalikesse kõnedesse põimitakse tihti humoorikaid retoorilisi kujundeid, et olla atraktiivne ja aktiveerida kuulajaid. 
Samade vahenditega võidakse teravalt kritiseerida oma vastaseid ja nende saavutusi. Tuntud retoorikameistrid (teiste seas Demosthenes, Aristophanes ja Archilochos - vt nende töödest lähemalt Kamińska-Szmaj 2007) kasutasid sageli sapist huumorit, samuti on seda teinud teiste ajastute poliitiline eliit ${ }^{3}$. Poola poliitiline satiir oli populaarne aegadel, mil Poola poliitiline eliit oli aktiivsem (nt 16. sajandil, humanismiperioodil, nn aadlike demokraatia kuldajastul, või 18. sajandi lõpul - valgustusajal, kui kirjanduses ja kultuuris domineerisid sotsiaalsed ja poliitilised teemad). Toonane poliitiline satiir kasutas sageli näiteid antiikajast, populariseerides Demosthenese, Lucanuse ja Horatiuse kirjanduslikke ja retoorilisi vorme ning ka neid žanre, millele pani humanismiajastul alguse Erasmus Rotterdamist ja hiljem Voltaire (vrd STL 1998). Selline päevakajaliste teemade käsitlus ilmnes erinevates avaliku elu valdkondades ja leidis edasist populariseerimist 17 . sajandi poliitilises komöödias (Poolas olid tuntud Julian Ursyn Niemcewiczi tööd). Poliitilise pilkenalja eesmärk oli osutada kodanike ja valitsevate poliitikute väärtegudele ja harida rahvast nalja abil, kuid see toimis ka poliitilise võimuvõitluse vahendina poliitiliste rühmituste ja vaimueliidi seas.

Poliitiline huumor esineb ka erinevates diskursustes (kõnekeele-, meedia- või poliitilises diskursuses) ja erinevates žanrites (nt nali, muud huumoripõhised verbaalsed vormid, kirjanduslik huumor, pildiline (joonistatud või fotopõhine) satiir) ja kunstilistes vormides (nt kabaree, jutusaated). Poliitilise huumori puhul on tegu ka erinevate kommunikatiivsete auditooriumitega (nt reaalmaailmas, internetis).

Poliitilise huumori mitmetahuline olemus on ka üks põhjus, miks seda kommunikatiivset nähtust on raske kirjeldada. Teine põhjus on arvukate naljade ja koomiliste tekstide eesmärk: paljud neist on mõeldud selleks, et naerda välja ja materdada oma ideoloogilisi vastaseid, ja nende sisuks on sageli pahatahtlik huumor ja ebaeetilised või vulgaarsed väljendid (vt Ożóg 2010).

Dorota Brzozowska (2009c: 115) väitel tungib mängulis-koomiline diskursus läbi kõigi teiste kommunikatiivsete väljade; see on "teatud tüüpi 'kommunikatiivne sündmus' mille puhul peamine idee ongi olla tahtlikult naljakas [...] ja interaktsiooni eesmärk on luua "naeru kogukond"'.

Lähtudes ülaltoodust võib poliitilist huumorit defineerida kui verbaalse ja mitteverbaalse käitumise summat, mis tekib kahe diskursiivse sfääri - avaliku ja mängulise - vastastikusel koostoimel; tegu on nende kommunikatiivsete kategooriate segunemisega. Humoorika tähenduse saamise vajalik eeltingimus on see, et omavahel kombineeritakse ja võetakse arvesse vähemalt kahel tasandil toimuv: 
- mentaalsel tasandil - hinnanguline, koomiline, keeleline kuvand poliitikutest ja nendega seotud olukordadest;

- pragmaatilis-lingvistilisel tasandil - kavatsus näidata poliitikat kõverpeeglis, s.t olemas on soov rääkida poliitikast, et 1) panna keegi naerma (kutsuda esile naer / heakskiit inimestes, kes mõistavad antud situatsiooni samamoodi); 2) naeruvääristada kedagi / midagi (et alandada poliitilise võimu esindajaid või kellegi poliitilist mõtlemist / poliitika tõlgendamist).

Poliitilise huumori stiili-ja žanripõhise klassifitseerimise raskus tuleneb tänapäeva keele, eriti poliitika- ja meediakeele üldisest positsioonist (vt KamińskaSzmaj 2001; Wojtak 2010). Avalikud väljaütlemised on allutatud ametlikule stiilile vaid situatsiooniga seonduvast vaatenurgast, tavaliselt on nad vabad ja loovad, ning (kvaasi-)kõnekujundid võivad esineda koos värvikate (nt kõnekeelsete ja naljakate) leksikaalsete vormidega (vrd Kudra 2001) ja tõsidus vastandatakse humoorikatele emotsionaalsetele kõneaktidele.

Selles avaliku diskursuse valdkonnas on palju osapooli ja kommunikeerijaid. Tänapäeva Poola poliitilises diskursuses kasutavad huumorit erinevad kommunikatiivsed kogukonnad erinevates pragmaatilistes olukordades.

- Poliitikud räägivad teistest poliitikutest humoorikalt - huumor toimib siin oponendi naeruvääristamise ja poliitilise võimuvõitluse moodusena; seda kasutatakse vastase tähtsuse vähendamiseks (valitsevate poliitikute või kodanike silmis).

- Meedia räägib avaliku elu persoonidest ja poliitilistest sündmustest humoorikas võtmes - mängulist atmosfääri, mis nende väljaütlemistega (nt uudisetekstides või poliitilistes kommentaarides) kaasneb, kasutatakse poliitilise satiiri või naeruvääristamise vormis (Wojtak 2010). Selle žanri - meelelahutus põimituna poliitikaga - olemus on näha vanades ajalehtede-ajakirjade karikatuurides. ${ }^{4}$ Tänapäevaseks vasteks on koomiksite pastiššid, fotoesseed ja videoklipid, kus kommenteeritakse peamisi uudisväljaandeid, ${ }^{5}$ mis oma sisus joonduvad info ja meelelahutuse, infotainmendi reeglite järgi.

- Kodanikud räägivad humoorikalt poliitikutest (ja poliitikast) - see on kõige ebastabiilsem ja mitmekesisem poliitilise diskursuse telg, sest selles viidatakse erinevate kogukondade poliitilistele kuvanditele ja arvamustele. Need kogukonnad väljendavad niimoodi oma ideoloogilisi uskumusi ja sümpaatiat/antipaatiat erinevate poliitikute suhtes. Sellist huumorit (pigem internetis kui näost-näkku suhtlemisel) levitavate või loovate inimeste pädevus sõltub nende ideoloogilisest identiteedist ja kuuluvusest. 
Ülaltoodud jaotus võiks hõlmata ka iroonilist eneseesitlust - s.t kommunikatiivseid strateegiad, mille abil räägivad poliitikud iseendast naljavõtmes. See ei ole küll tavapärane, kuid mõned poliitikud kasutavad seda üha rohkem kommunikatiivse mängu elemendina või uue tavana poliitilises etiketis. Tänapäevased poliitilised naljad on seetõttu mitmekesised nii sisult kui stiililt. Neist saavad õigesti aru inimesed, kel on samasugune huumorimeel, tundlikkus ning võime mõista assotsiatsioone ja sõnamänge, ja ühine aksioloogiline süsteem. See käib peamiselt olulisemate poliitiliste parteide esindajate väljaütlemiste või nendega seonduvate naljade kohta. Pidevalt põrkuvad erinevad arusaamad, ja seda kajastatakse eriti just pressiväljaannetesse ja internetiportaalidesse kogutud naljades. Nendes naljades väljendub Poola ideoloogiliste identiteetide polariseeritus (täheldatav on see kahe erakonna - Kodanike Platvormi PO (Platforma Obywatelska) ning Õiguse ja Õigluse Partei PiS (Prawo i Sprawiedliwość) kohta käivates naljades, kus satiiri objektideks on peaminister Donald Tusk või opositsioonipartei liider Jarosław Kaczyński).

Tänapäeva poliitilist huumorit defineerida püüdes tuleks kindlasti rääkida ka diskursuse teooriast. Diskursuseanalüüsi metoodika interaktiivses käsitluses (mille on välja töötanud Michael Halliday ja John Firth ning mida arendas edasi Teun A. van Dijk 2001: 162) tuuakse välja järgmised metafunktsioonid: mentaalne, interpersonaalne (interaktiivne) ja tekstiline / tekstilis-stilistiline. Mängulisuse diskursus sensu largo ja selle mõju teistele kommunikatiivsetele sfääridele (Brzozowska 2009c) lisab poliitilisele huumorile lisaks muule ka alljärgnevad funktsioonid:

1. Mentaalsel tasandil - poliitiliste naljade ja lugude rääkimine väljendab suhtluskogukondade aksioloogilist ja ideoloogilist identiteeti. See on seotud tõigaga, et naljad peegeldavad poliitilise reaalsuse diskursiivseid sümboleid ja arvukaid kõnekeelseid igapäevaseid kontseptualisatsioone (M. Fleischeri termin), mis näitavad poliitiliste sündmuste kuvandeid, arenguid ja neisse suhtumist (heakskiit / taunimine) kõnekeele tasandil. Need suhtumised võivad väljenduda naljade tsüklis, nt naljad, mis põhinevad Tuski ja Kaczyński vastandamisel, ja mis intertekstuaalses vormis viitab nende kahe partei (PO - PiS) lahknevusele poliitilisel areenil.

2. Interaktiivne / pragmaatilis-lingvistiline tasand - poliitikute, ajakirjanike ja suhtluskogukondade humoorikad lausungid eesmärgiga: a) panna naerma samasuguse ideoloogilise identiteediga või sarnase huumorimeelega inimesed; b) diskrediteerida teisi poliitikuid (või gruppe); c) kritiseerida avaliku elu negatiivseid aspekte.

3. Tekstiline tasand - poliitiline huumor esineb paljudes poliitilise kommunikatsiooni väljendustes: a) ametlikus käibes (nt meedias, internetis, poliitiliste sündmuste ametlikes aruannetes); b) suletud, hajutatud (või 
efemeerses) kommunikatiivses käibes, nt verbaalsed naljad ja humoorikad väljaütlemised värvikas kõnekeeles või hoolikalt läbimõeldud jutustused satiirilistes internetiportaalides.

\section{Poliitiline huumor Poola Rahvavabariigi päevil ja tänapäeval - võrdlev pilguheit}

Kuigi rahvavabariigi aegadel räägiti poliitilisi nalju üksnes suletud ringis, on nad heaks näiteks äärmiselt mitmekülgsest ja erilaadsest naljakultuurist, eriti võrreldes tänapäeva Poola huumoritraditsiooniga internetis ja suulises pärimuses. Põhjuseks on see, et PRV-aegsed naljad väljendasid toonase Poola ühiskonna kollektiivset identiteeti ja arvamusi poliitilisest olukorrast, vastandudes totalitaarsele propagandale; naljad tõid välja ümbritseva sotsiaalse reaalsuse puudused ja absurdsuse ning väljendasid keelatud sotsiaalset või ideoloogilist suhtumist, mis ei sobitunud ametliku kommunikatiivse seisukohaga.

Suulises suhtluses ringelnud keelatud poliitiline huumor oli populaarne mitte ainult seepärast, et see vihjas võimalusele kummutada domineeriv ideoloogia, mida juurutas avalikus suhtluses levitatav monotoonne propaganda ja mille autoriks oli poliitiline võimuladvik (vt Głowiński 1992; Bralczyk 2001; Kamińska-Szmaj 2007; Dytman-Stasieńko 2007 jt). Eelkõige oli see populaarne tabuteemade kasutamise tõttu. Poliitiline huumor lõi jalad alt kommunistliku partei kommunikatsioonimonopolil ja asendas selle mänguliste poliitiliste kommentaaridega, mis olid kättesaadavad vaid igapäevastes mitteametlikes suhtlussituatsioonides (vt ka Rebane 2012).

Seda informaalse suhtluse aspekti markeeris äärmiselt rikas kogum suulise narratiivi vorme, millest mõned, hoolimata muutunud reaalsusest, resoneerivad ikka veel ning neid kohandatakse innukalt praegustele vajadustele tänapäevastes internetiportaalides.

Uurijate väitel on Poola sotsialistlikud naljad jaganud sama saatust nagu teiste NSV Liidu mõjuvõimu all olnud Euroopa riikide naljad (vrd Davies 2009; Laineste 2009; Brzozowska 2009a, 2009b jt). Sotsialistlikku naljakultuuri iseloomustasid arvukad narratiivid, mis naeruvääristasid poliitvõimu ja kommunistliku parteiaparaadi esindajaid (Brežnev, Gierek, Gomułka, Jaruzelski). Ühised teemad näitasid elu absurdsust sotsialistliku doktriini mõju all (nt naljad nõukogude "teadlaste" leiutistest, Jerevani raadio propagandasaated), ja ka toonase geopoliitilise olukorra tõlgendused "raudse eesriide" taga olevates riikides (nt kommunistlike juhtide "sõbralikud töövisiidid” omaenda ringkonnas või nende diplomaatilised kokkusaamised tippkohtumisel riigipeadega väljaspool idablokki - nt naljad Reaganist ja Gorbatšovist). 
Kõik need žanrid vastandusid survestavale ja monotoonsele kompartei propagandale, mis püüdis omakorda allutada huumorit poliitilisele doktriinile ja näitas huumori suhtes üles üsnagi halvustavat suhtumist. Rääkides ametlikest poliitilistest naljadest Poola Rahvavabariigi perioodil, tuleks teiste seas mainida satiirilisi joonistusi ja plakateid, kus materdati poliitilisi vastaseid (nn ideoloogilist vaenlast) või käitumisviise, mida parteiametnikud põlgasid või mis oli neile keelatud (nt plakatid, millel naeruvääristati looderlust, alkoholi kuritarvitamist, rahvavaenlasi, ja kus direktiivsed üleskutsed, keelud ja käsud edastati "harivas" stiilis lausungitega nagu Ole valvel!; Ära eira! jne).

Sellise režiimi propaganda, mis toimis naeru ja pila abil, väljendus ka plakatites, mis olid täis pahatahtlikku irooniat ja kus võideldi näiteks selle eest, et ei kuulataks raadiojaamu väljaspool raudset eesriiet - Raadio Vaba Euroopat ja BBC raadiot. Lõikava satiiri sihtmärkideks olid vähese intellektuaalse võimekusega ja koomilise väljanägemisega tegelased; negatiivseid assotsiatsioone rõhutatakse siltidega nagu imperialistlik, kodanlik, reaktsiooniline jne.

Sageli korduv pankuri- või kapitalistifiguur on nende tähenduste kandja. Semantilises plaanis leiab veel ühe kujundi, mis seondub Poola traumaatiliste sündmustega Teises maailmasõjas: visuaalne metonüümia "illegaalsest raadiost" kui natside süljetopsist, haukuvast valjuhääldist (s.t sakslaste tänavatele paigaldatud valjuhääldid, mille kaudu okupandid levitasid Poola inimestele vastuvõetamatut pealetükkivat informatsiooni). Lääne infokanalite suhtes üha kasvava vaenulikkuse ja hirmu õhkkonnas vaidlesid "harivad" luuleread vastu kapitalisti-kujule - ad absurdum vormis ja ad baculum sisuga -, nagu järgnevas näites:

- Stuchat, stuchat Bibisyna [radia BBC], à் mu spuchta tepetyna.

- Dureń, co stucha [RWE] z mina tak błoga.

Komu pomaga? Śmiertelnym wrogom.

[Ta kuulas Bibisyni [BBC raadiot] / ja see tekitas talle jubeda peavalu. / - Kes see loll nii õndsa näoga Raadio Vaba Euroopat kuulab. / Keda ta aitab? Oma surmavaenlast.] (www.ipn.gov.pl)

Poliitiline huumor PRVs oli vormiliselt väga kirev ja rohkete kommunikatiivsete skriptidega, mis ringlesid kõnekeelses, suulises käibes. Selle kõrge tase peegeldub ka teistes koomilistes žanrites (peamiselt kabarees ja arvukates satiirilistes ja meelelahutussaadetes), mida populariseeris kunstiline eliit. Loomulikult allus mängulis-naljakas sisu tsensorite kontrollile, kuid koomikutel õnnestus alatasa sisse smugeldada vihjeid valitsevatele poliitikutele. Vastavad näited hõlmavad nii kabareeõhtuid Poola riiklikul laulufestivalil Opoles, uusaasta nukuteatrietendusi, mis tavaliselt kanti üle pärast Poola Ühendatud 
Tööpartei (PZPR) peasekretäri ametlikku uusaastaläkitust, vihjeid täis dialooge telekabareedes "Olgi Lipińskiej” ja "Starszych Panów", meelelahutuslikke raadiosaateid "60 minut na godzinę" (60 minutit tunnis), "Z pamiętnika młodej lekarki” (Noore arsti päevikust) jne.

Ühiskondlikud ja poliitilised ümberkujundused pärast 1989. aastat muutsid ka poliitilist, avalikku ja ajakirjanduslikku kommunikatsiooni (vrd teiste seas ka Kamińska-Szmaj 2001 ja 2007; Bralczyk 2001; Bralczyk \& Mosiołek-Kłosińska 2001; Ożóg 2004; Anusiewicz \& Siciński 1994 jt) ning mõjutasid anonüümset poliitilist folkloori ja huumorit. Nüüd hakkas see ilmuma kommentaaridena ametlikus kommunikatiivses diskursuses. Irena Kamińska-Szmaj sõnul "kaotas naljade rääkimine mitteametlikus olukorras oma atraktiivsuse "keelatud viljana" [...] spontaansed ja anonüümsed huumorivormid on asendunud autorite koomiliste hinnangutega poliitilistele sündmustele naljade, lühiluuletuste, olemuslugude või satiiriliste karikatuuridega" (Kamińska-Szmaj 2001: 189-90).

Nendele järeldustele tuleks lisada veel üks kommentaar: kvaliteedierinevus Poola Rahvavabariigi aegsete ("keelatud" / "sosistatud" naljade) ja tänapäeva Poola poliitiliste naljade ("poliitiline folkloor", "poliitmeelelahutus") vahel on täheldatav eelkõige pragmaatilis-lingvistilisel tasandil, s.t keelelises käitumises neis suhtluskogukondades, kellele pakub lõbu näidata poliitikat kõverpeeglis ja peegeldada naljade kasutamise olukorraga seonduvaid asjaolusid (nalja rääkimine kui märk mingi tabu eiramisega kaasnevast rõomust PRVs versus nalja rääkimine kui märk intertekstuaalsest mängust erinevate poliitiliste vaadetega kogukondade vahel).

Muutus naljade potentsiaal rikkaliku variatiivsuse allikana ning ka nende esteetiline kvaliteet. Enne 1989. aastat pärit naljadel on iseloomulikult eriomased ja korduvad komponendid: nt äratuntav tekstiline piiritletus, s.t ühesugused narratiivsed vormelid alguses (sissejuhatus) ja lõpus (puänt); kõikehõlmavad aksioloogilised stereotüübid kirjeldatavate kangelaste/tegelaste osas; stereotüüpne ja selgepiiriline suhestumine poliitilise ja ajaloolise reaalsusega - nt tavapärased kolm tegelast (poolakas, venelane ja sakslane), kes olid satiirilised natsidest okupantide suhtes, asendusid hiljem teiste tegelastega, nt naljades, kus esitati külma sõja reaalsusi ja tegelasteks olid poolakas, venelane ja ameeriklane. ${ }^{6}$ Kuna tänapäevase poliitilise satiiri sisu on vähem formaliseerunud, jõuab see igapäevakeelde vähemal määral. Nüüd on sisuks juhuslikud jutustused, teravmeelsed märkused, ütlused ja väljendid, mis on telesõude (nt "Szymon Majewski Show", "Szkło kontaktowe") ja interneti visuaalformaatide (fotoblogid, karikatuurid ja joonistused portaalides, videoklipid või nn demotivaatorite kogud; vt ka Baran 2012) mõjul käibel vaid lühikest aega. Suuliste naljatekstide äratuntavat repertuaari esineb igapäevakeeles üha harvemini. Teisisõnu on sõnaline poliitiline huumor (nagu teisedki popkultuuri vormid) 
allutatud meedia ja üleilmastumise mõjule ning on killustunud. Mänguliste elementide edukus ja täpsus naljades ei tugine enam nendes sisalduvatele tabavatele vihjetele, vaid eelkõige nende mõjuväljale suhtluskogukondades.

Ülaltoodud võrdlev analüüs on kokkuvõtvalt esitatud tabelis:

\begin{tabular}{|c|c|}
\hline $\begin{array}{l}\text { POLIITILINE HUUMOR } \\
\text { POOLA RAHVAVABARIIGIS }\end{array}$ & $\begin{array}{l}\text { POLIITILINE HUUMOR } \\
\text { TÄNAPÄEVAL }\end{array}$ \\
\hline $\begin{array}{l}\text { - keelatud ametlikus poliitilises } \\
\text { propagandas (näit poliitikute amet- } \\
\text { like kõnede ajal), allus tsensuurile, } \\
\text { mis normeeris ja lubas vaid teatud } \\
\text { määral ja meelevaldselt selekteeri- } \\
\text { tud mängulis-humoorikat sisu } \\
\text { - keelatud ka igapäevasuhtluses } \\
\text { (võttis nn sosistatud naljade kuju) }\end{array}$ & $\begin{array}{l}\text { - vaba, piiramatu, hõlmab erinevaid kom- } \\
\text { munikatiivseid olukordi } \\
\text { - esineb ka ametlikus suhtluses (nt par- } \\
\text { lamendiistungitel, pressikonverentsidel, } \\
\text { valimiskoosolekutel ja poliitikute meedia- } \\
\text { esinemistes) }\end{array}$ \\
\hline $\begin{array}{l}\text { - kaks eraldi kommunikatsioonika- } \\
\text { nalit: } \\
\text { 1. ametlik, s.t poliitikute poolt nor- } \\
\text { meeritud, et pilgata ja teha naeru- } \\
\text { vääristavat propagandat poliitiliste } \\
\text { vastaste (vaenlase) suhtes } \\
2 . \text { mitteametlik - tõeline poliitiline } \\
\text { huumor, kuhu kuulub terve kogum } \\
\text { nalju, mille kaudu kodanikud naeru- } \\
\text { vääristasid režiimi, poliitikuid ja par- } \\
\text { teiaparatuuri }\end{array}$ & $\begin{array}{l}\text { - kaks kattuvat kommunikatsioonikana- } \\
\text { lit: } \\
\text { 1. ametlik - huumor, mille on loonud arvu- } \\
\text { kad autorid, mida populariseeritakse mee- } \\
\text { dias, veebilehtedel ja meelelahutusprog- } \\
\text { rammides ja mis esineb üllatusmomendina } \\
\text { ka poliitilistel üritustel } \\
\text { 2. mitteametlik - vabalt levitatav igapäe- } \\
\text { vases poliitilises suhtluses; edastajateks } \\
\text { on erinevatesse suhtluskogukondadesse } \\
\text { kuuluvad inimesed (kel on erinevad väär- } \\
\text { tused ja ideoloogilised tõekspidamised) }\end{array}$ \\
\hline $\begin{array}{l}\text { - tekib mitteametlikus igapäeva- } \\
\text { suhtluses, kuid nalju loovad ka intel- } \\
\text { lektuaalid ja kunstieliit (nt teleka- } \\
\text { bareed või festivalidel korraldatavad } \\
\text { kabareeõhtud) }\end{array}$ & $\begin{array}{l}\text { - naljakad tekstid (erineval esteetilisel ja } \\
\text { kunstilisel tasemel), kohandatud peami- } \\
\text { selt popkultuuris kasutamiseks, tavaliselt } \\
\text { kunstieliit naljade loomisel eriti ei osale } \\
\text { (kabareeõhtud ja poliitilise satiiri saated } \\
\text { televisioonis ei ole populaarsed) }\end{array}$ \\
\hline $\begin{array}{l}\text { - rikkalikud üldtuntud ja mõiste- } \\
\text { tavad naljad, milles kasutatakse } \\
\text { korduvaid skripte ja klišeesid poliit- } \\
\text { võimu esindajate kohta - peamiselt } \\
\text { Gierek, Jaruzelski, Gomułka. Osa- } \\
\text { liselt on see narratiivne struktuur } \\
\text { laenatud NSV Liidust (Brežnev, Sta- } \\
\text { lin, Gorbatšov jne) }\end{array}$ & $\begin{array}{l}\text { - mitmed efemeersed naljaseeriad kodu- } \\
\text { maistest ja maailmas tuntud poliitikutest, } \\
\text { nt laenudena angloameerika meelelahu- } \\
\text { tusprogrammidest või poliitilise satiiri } \\
\text { veebilehtedelt; enamasti on tegu vana, } \\
\text { sotsialistliku anekdoodi kohandamispüü- } \\
\text { dega (uuteks tegelasteks nt Putin, Merkel, } \\
\text { Obama, Tusk) }\end{array}$ \\
\hline
\end{tabular}

Tabel 1. Poola Rahvavabariigi aegse ja tänapäeva poliitilise huumori võrdlus. 


\section{Poliitiliste lendsõnade kommunikatiivsed ja intertekstuaalsed karakteristikud}

Tänapäeva sotsiaalsuhtluses (nii kõnekeelses kui ka ametlikus) edastatakse huumoritekste harva suuliste poliitiliste anekdootidena (s.t sarnaste skriptide, teemade ja puändiga folkloorsete narratiividena). Selle asemel pakutakse välja tsitaate, fraseeme või parafraase poliitikute kõnedest, ning allikmaterjali emotsionaalse sisu, üllatavate assotsiatsioonide ja hinnanguliste vihjete tõttu tungivad need poliitilised naljad meedia kaasabil erinevatesse diskursuse sfääridesse. Ootamatud vahejuhtumid, mis lõhuvad või rikuvad ametlike suhtlusolukordade tõsidust, on tänapäeval kõige sagedasemaks poliitilise huumori allikaks.

Kohatud sõnad või teod poliitikute ja diplomaatide käitumises, keelevääratused ja pentsikud väljaütlemised, mis ei sobi tõsisesse poliitilisse õhkkonda, või ebaloogilised, keelereegleid eiravad lausungid - ajakirjanikud korjavad kõik need apsakad väga kiiresti üles ja seejärel hakkavad need elama omaenda mängulist elu erinevates intertekstuaalsetes kontekstides - alguses massimeedias ning hiljem, anonüümsete autorite poolt populariseerituna, erinevates virtuaalkogukondades. Ühelt poolt kasutatakse neid lendsõnu, mida poliitikamaailma esindajad on välja öelnud (vt Chlebda 2005; Kita 2000), selleks, et esitada raskeid probleeme värvikalt, lihtsalt ja kergesti mõistetavalt (nt poliitiliste sündmustega seotud terminoloogia või tõlgendused), kontseptualiseerides assotsiatsioone selle suhtlusolukorraga, kus nad ilmnesid. Teisalt jõuavad avaliku elu tegelaste keelevääratused poliitilisi sündmusi kommenteerivatesse ajalehtedesse, meelelahutusprogrammidesse ja virtuaalsetesse kogudesse uues intertekstuaalses vormis, eesmärgiga naeruvääristada nende ütluste autorit. Samas on ka tögav poliitiline kommentaar (vt Wojtak 2010) populaarne poliitilise huumori žanr. See "nähtav või pigem kuuldav" (Kamińska-Szmaj 2001: 189) huumoriliik esineb parlamendiistungitel (värvikad verbaalsed ja mitteverbaalsed reaktsioonid pannakse hoolikalt protokolli kirja märkusena: nt elevus saalis), pressikonverentsidel, intervjuudes nii ametlikus (nt telestuudios) kui ka mitteametlikus (nt ajakirjaniku ootamatu kokkusattumine poliitikuga parlamendihoone koridorides, telefonikõned jne) olukorras. Enamik neist tekstidest põhineb üllatusel (inkongruentsus), ${ }^{7}$ seega tugineb nende huumoripotentsiaal kiirele verbaalsete ja mitteverbaalsete tähenduste dekodeerimisele ja ametlike sündmustega kaasnevatele koomilistele situatsioonidele.

Ametlikus poliitilises kommunikatsioonis ilmneva situatsioonipõhise verbaalse huumori pragmaatilisi jooni on kirjeldanud Irena Kamińska-Szmaj. Tema uurimistöö keskendub Poola parlamendiliikmete naljakatele väljaütle- 
mistele. Kamińska-Szmaj (2001: 131-132) on välja toonud järgmised koomilise teksti funktsioonid:

1. Teraapiline (emotsionaalne) - naer on reaktsioon ootamatule olukorrale, kui poliitiliste sündmuste osaliste ideed ja mõtted tõsisest avalikust diskursusest satuvad omavahel konfrontatsiooni (nt parlamendidebattidel, pressikonverentsidel). Tavaliselt haarab naer kõik sündmuses osalejad; see on mitteverbaalne signaal dekodeerimaks kahte üksteist välistavat kommunikatiivset skripti ning see pole algatatud negatiivsetest tunnetest konkreetse inimese vastu.

2. Integratsioonile suunatus - nalja saab samamoodi dekodeerida ühte "naljakogukonda" kuuluv auditoorium (poliitikute puhul inimesed, kes kuuluvad samasse intellektuaalsesse ja ideoloogilisse kogukonda). Rõómutunnet jagavad rühma kõik liikmed, kes on motiveeritud ja suutelised dekodeerima huumorit (peamiselt selle kaas- ja kõrvaltähendusi), mis sisaldub lausungis, mis teiste inimeste kõrvus kõlab tõsiselt. Selline huumor on ühele rühmale märk rahulolust ja teisele nördimuse väljendamine. Seetõttu saab seda kasutada poliitilises poleemikas kui strateegiat poliitilise maastiku polariseerimiseks dihhotoomsete (aksioloogiliselt vastastikku üksteist välistavad) kogukondade vahel - "meie" versus "nemad".

3. Demotiveerimine - see on kõige tavalisem poliitilise võimuvõitluse vahend. Teatud väljaütlemise (nalja või iroonilise sõnamängu) naljakat tähendust või selles ilmnevat humoorikat skripti kasutatakse lausungi sihtmärgi alavääristamiseks. Koomiline kõneakt muutub seega solvavaks. Pilkavat naeru dekodeeritakse poliitilises diskursuses sageli solvanguna.

Järgnevalt tuuakse näiteid sellistest humoorikatest poliitilistest väljaütlemistest. Materjal on kogutud huumorisaatest "Hõbesuu", mida andis eetrisse Poola Raadio III programm alates 1992. aastast, saatejuhiks Beata Michniewicz. Tegu oli võistlusega, kuhu esitati tsitaate poliitilistest debattidest ja muudelt sündmustelt, kõige naljakam ütlus selgitati välja kuulajate hääletusega ning võitja sai auhinna "Hõbesuu". Vaatluse alla tulevad kommunikatiivsed (pragmaatilised) aspektid neis tekstides, mis panid teatud osa raadiokuulajatest naerma, kuid jättis ülejäänud vaatlejateks / kommentaatoriteks:

Biada temu pięknemu i historycznemu miastu Kraków! Biada krakowskiej inteligencji, jeśli w Sejmie musi ja prezentować poset Jan Rokita!

[Häda ilusale ajaloolisele Krakówi linnale! Häda Krakówi vaimueliidile, / kui selle esindajaks parlamendis on Jan Rokita!] 
Nii väitis parlamendiliige Samooborona (enesekaitse) fraktsioonist, mida üldiselt süüdistatakse populismis; rühma toetajaid peetakse madala sotsiaalse staatusega inimesteks. Huumor põhineb sellises olukorras peamiselt sõnumi saatja ja vastuvõtja vastanduvatel skriptidel (parlamendiliige, kes esindab vähem edukaid sotsiaalseid rühmitusi versus "Krakówi intellektuaalid"). Selles ütluses on laenatud elemente mütoloogilisest Kassandra needusest; kasutatud on tekstilise allika mõneti arhailist ja kirjanduslikku stiili, mis eeldatavasti assotsieerub Kassandrast kõneleva tragöödia poolakeelse versiooniga, mille autoriks on Jan Kochanowski.

Panowie z PiS-u, naprawdę, nie lękajcie się!

[Härrased PiSist, tõesti, palun ärge kartke!]

Sellest naljast saab aru ainult kontekstile viidates - ütluse autor pöördus kaasparlamentääride poole PiSist (Õiguse ja Õigluse Partei), kes oma ideoloogilises programmis on viidanud kristlikele väärtustele. Vormel "ärge kartke" on seega selge parafraas tsitaadist, mis on võetud paavst Johannes Paulus II apostellikust pöördumisest, seega on tegu viitega alltekstile "Parlamendiliikmed PiS parteist, ma räägin teiega kasutades religioosset kõnekeelt, kuna ma ei ole suuteline teid veenma parlamentaarse keele abil".

Jestem tylko skromnym prawnikiem prezydenta [Wałęsy].

[Ma olen vaid president Wałęsa tagasihoidlik jurist] (tähenduses 'ma ei ole suurmees / tähtis kala')

Siin fragmendis on tunda võltstagasihoidlikkust, mis ongi nalja põhjustajaks. Selle lause ütles professor Lech Falandysz, kes oli üks kõige olulisemaid seaduste ja seadusandlike reformide algatajaid Poola taasdemokratiseerumise alguspäevil 1990. aastatel. Professori kritiseerijad süüdistasid teda seaduste allutamises poliitilistele eesmärkidele, ja tuletisest falandyzacja saigi laialt kasutatav idioom - tipp-poliitikute sellise käitumise tähistamiseks - esmalt kõnekeeles ja seejärel juurdudes ka ametlikus keeles. Ilmselgelt ongi kuulajaskonna oskus dekodeerida iroonilist võltstagasihoidlikkust selles eneseesitluses nalja allikaks.

Nie można mieć pretensji do stońca, że się kręci wokót Ziemi.

[Ei saa süüdistada päikest Maa ümber tiirlemises.]

Selles Lech Wałęsa öeldud lauses põrkuvad kaks tähendust: ühelt poolt on tegu hariva ja direktiivse kommentaariga, mis viitab lihtsale ja igapäevasele maailmakäsitlusele, teisalt on huumori allikaks tehtud loogikaviga.

Członek - to brzmi dumnie! (versus Człowiek - to brzmi dumnie!)

[Liige [peenis] - see kõlab uhkelt!] (versus: inimene - see kõlab uhkelt!) 
Selle (metateesil ja homonüümial põhineva) keelevääratuse kummalisus tekitas arvatavasti frivoolseid konnotatsioone kuulajaskonnas. Asjakohase ja tõsise kõnekujundi asemel on siin tekkinud hoopis seksuaalne tähendus, mis on ametlikus suhtluses tabuteema.

Na pytanie udzielone Super Expressowi powiedziat pan: "Wy ze mnie tu alfy i omegi nie róbcie. Ja znam tylko konkrety ogólne!” [...] Będę głosowat za tym, żeby przyznano panu "Srebrne usta".

[Te vastasite Super Expressi ajakirjaniku küsimusele nii: “Ärge püüdke teha minust alfat ja oomegat. Ma tean ainult üldisi spetsiifilisi fakte!" [...] Niisiis, ma hääletan selle poolt, et te võidaksite "Hõbesuu" auhinna.]

Taas tuleb seda parlamendidiskussioonis tekkinud verbaalset nalja lugeda metakommunikatiivsest tasandist lähtudes. Selle autor viitab pilkavalt kõnekujundile, mida kaasarutleja on väga kummaliselt kasutanud; veelgi enam, ta peab seda mittetõsiseks ja väheväärtuslikuks ütluseks, mida tuleks satiirilises meediasaates naeruvääristada.

Ülaltoodud näited kontekstuaalsest verbaalsest huumorist keelevääratustes, korralikult läbimõtlemata ütlustes või kohatutes prohmakates pakuvad üllatusmomenti sellega, et väljaöeldu on vastuolus auditooriumi stiililiste ja pragmaatiliste ootustega. Teisisõnu kasutatakse inkongruentsusel põhinevat koomilist mentaalset konstruktsiooni, mida määratletakse kui "vastuolu selle vahel, mida me ootame, ja mis tegelikult juhtub" (Kucharski 2009: 12). Tavaliselt seletatakse tekstide "mitte-heauskset" lugemisprotsessi sellega, et naljad kutsuvad esile vastuolulisi skripte, s.t et skriptid on vastastikku üksteist välistavad sisu, antonüümilise tähenduse või kõneakti kavatsusliku tähenduse osas (Victor Raskini ja Salvatore Attardo teooria, osundanud Lew 2000 jt), nt kui:

1. vastuvõtja tõlgendab ütlust vastupidiselt sõnumi saatja kommunikatiivsele kavatsusele;

2. ütluse vorm ja keelekasutus on vastuolus konkreetses olukorras nõutava stiili või žanriga;

3. keelelised vahendid on nii mitmetähenduslikud, et nad tekitavad allusioone teiste kommunikatiivsete skriptidega.

Käesolevas artiklis on raske välja tuua kõiki lingvistilisi allikaid ja vahendeid, mis aktiveeruvad situatsioonile orienteeritud huumoris. Peamiselt on tegu alljärgnevatega.

- Keel ja loogikavead, keelevääratused, libastumised ja enda parandamised, mis võivad olla kriitika (pilke) objektiks, suunatuna mingile sihtmärgile või kellegi mõtetele: 
Żadne krzyki i ptacze nas nie przekonaja, że biate jest biate, a czarne jest czarne.

[Isegi karjumine ega nutmine ei veena meid, et valge on valge ja must on must.]

Wiele wskazuje na to, że wrócimy z Kopenhagi na tarczy...y..., nie na tarczy, a z tarczq-przepraszam... odpukać! ... Straszne rzeczy!

[Mitmed märgid näitavad, et tuleme Kopenhaagenist tagasi kilbil [lüüasaanutena] ... ee... mitte kilbil, vaid kilbiga [võitmatutena] - vabandan ... katsu puud (sülita kolm korda)!... Oh, kui õudne!]

- Homonüümia, polüseemia ja metonüümia tõttu tekkinud semantilised vastuolud:

Oświadczam, że nigdy nie bytam księdzem.

[Siinkohal teatan, et ma ei ole kunagi olnud preester.] (Parlamendi naisliige, kes on kuulus oma teravate märkuste poolest; siin vastas ta nendele parlamendiliikmetele, kes süüdistasid teda asjatundmatuses kirikuga seonduvate probleemide osas.)

Ja zdaję sobie $z$ tego sprawę, że muszę być $i$ caty czas będę, między mtotem a kowadtem, ale już lepiej być między mtotem a kowadtem niż między mtotem a sierpem.

[Saan aru, et ma pean olema ja olen ka tulevikus kogu aeg alasi ja haamri vahel, aga parem ongi olla alasi ja haamri kui sirbi ja vasara vahel.] (Naljakas fraseoloogiliste elementide kontaminatsioon leksikaalse metonüümiaga, viitega NSVLi sümboolikale.)

- Omavahel sobimatute erinevate stilistiliste vahendite kontaminatsioon (k.a eriti kõnekeelsete elementide toomine ametlikku stiili):

Ja już nie szukam pieniędzy za ksiażki, bo te catkowicie udupitem $w$ sprawach spotecznych...

[Ma ei otsi enam raamatute jaoks raha, sest olen sotsiaalses mõttes kõik persse keeranud...]

Odczuwam nieodparta potrzebę, jak patrzę na ten uśmiech $i$ na to spojrzenie w bezkresna dal bezrefleksyjnie utkwione, żeby zadedykować panu premierowi refren z pewnej kabaretowej piosenki: "Co by tu jeszcze spieprzyć, panowie, co by tu jeszcze spieprzyć?”

[Ikka veel tunnen vajadust... kui vaatan seda naeratust... ja seda kaugusesse suunatud pilku, kus puudub igasugune eneserefleksioon... tunnen 
vajadust pühendada meie peaministrile ühe kabareelaulu refrääni: "Mida me veel saaksime tuksi keerata, härrased, mida veel saaksime tuksi keerata?"]

- Ebamõistlik stiilikasutus (nt on kõnekujundid valitud mitte poliitilisest, vaid mingist muust diskursusest):

Gratuluję premierze i szczęść Boże na dalszq drogę rządzenia!

[Palju õnne, härra peaminister, ja jumal õnnistagu teid jätkuvas valitsemises!] (Religioossest keelepruugist võetud soovivormel kui vihje kutsuda poliitilise partei esindajat üles kristlike väärtuste kaitsele.)

- Varjatud vihjed poliitikamaailma persoonidele ja sündmustele:

Przybytem tutaj, aby z gtębokim bólem poinformować Państwa, że postowie Jacek Kurski i Arkadiusz Mularczyk to moje wielkie porażki pedagogiczne. [Olen tulnud siia, et teile raske südamega teada anda, et parlamendiliikmed Jacek Kurski ja Arkadiusz Mularczyk on minu kaks pedagoogilist läbikukkumist.]

- Liiga emotsionaalsed (liialdatud) väljaütlemised / kõnekujundid:

Idac torem logicznym własnego rozumowania: nie mam pytań... [Järgides arutluse loogilist teekonda: mul ei ole rohkem küsimusi...]

- Debatis osalejatele suunatud apostroofid, mis paljastavad vastuolu poolviisaka vormi ja tegeliku solvamissoovi vahel (pilkamine, sihtmärgi avalik mahategemine):

Pani poset - proszę mi wybaczyć, ale obawiam się, że Pani owies uderzyt do glowy...

[Proua... - palun vabandage mind, aga ma kardan, et te olete liiga palju kaera söönud...] (viide sama naissoost parlamendiliikme varasemale avaldusele, et talle meeldib seks sama palju kui hobusele kaer).

Mam dwa pytania. Jedno pytanie do pana premiera i z cała powaga prosze potraktować to pytanie. Panie premierze, mam wrażenie, $i$ to nie tylko ja mam wrażenie $w$ Polsce, że często pan stoi $w$ rozkroku?

[Mul on kaks küsimust. Üks küsimus on meie peaministrile ja palun teil võtta seda täie tõsidusega. Härra peaminister, mulle on jäänud mulje, ja ma pole ainus Poolas, mulle tundub, et te seisate liiga tihti harkisjalu.]

- Hästituntud metafoorsete, humoorikate ütluste, võrdluste ja fraseemide modifikatsioonid (tuletised): 
Kura najpierw jajko zniesie, a dopiero potem gdacze. Nasi polityczni przeciwnicy gdacza, nawet kiedy nie potrafia jajka znieść.

[Kana muneb esmalt muna ja alles siis kaagutab. Meie poliitilised vastased kaagutavad isegi siis, kui nad muneda ei suuda.]

\section{Kokkuvõte}

Ülalkirjeldatud vormelitel on lendsõnade staatus, s.t nad on fraseemilised leksikaalsed üksused, mis käibivad intertekstuaalselt tsitaatidena (Chlebda 2005). ${ }^{8}$ Selliste fraaside atraktiivsust kinnitab nende suur kommunikatiivne mitmekesisus (võime luua uusi tähendusi tekstides, s.t kõrge intertekstuaalsus), kuid eelkõige nende suutlikkus vihjata tähenduslikult uutele poliitilistele allusioonidele, mitmekordistades nende ütluste mängulist potentsiaali erinevates žanrites ja erinevat tüüpi sensu largo diskursustes. ${ }^{9}$

Poliitilisi tekste, 1) mis sisaldavad kavatsuslikku huumorielementi (kus saatja räägib selleks, et tekitada naeru / panna keegi naerma / naeruvääristada kedagi või midagi) ja 2) mis ei sisalda kavatsuslikku huumorit, kuid mida saab siiski niimoodi lugeda (kus ütleja ise tekitab mittetahtlikult kuulajates naeru või satub ebapädeva keelekasutuse tõttu naeru sihtmärgiks), avaldavad ajakirjanikud tavaliselt seepärast, et need tekstid kannavad sõnumit: "Tähelepanu! Midagi on toimumas!”. Sellega väljendavad nad tänapäevase ajakirjandusmaailma kõige olulisemat aspekti - sensatsioonihimu, emotsionaalsust, valjuhäälsust ja infotainmendi e meelelahutusliku informatsiooni poeetikat (vt Bauer 2000; Godzic 2004). Fraase populariseeritakse kui leksikaalseid (derivatiivseid) meediadiskursuse ühikuid ja neist on saanud idioomid praeguses kõnekeelses tähenduses või teiste (mitte üksnes huumori-) tekstide elemendid. Naljakate ütluste rituaalse kordamise populaarsust kinnitavad kõige paremini meelelahutussaadete (nagu raadiosaade "Hõbesuu") staatus, kus kuulajad või vaatajad valivad välja poliitikute kõige naljakamad lausungid.

Arvukad sedalaadi väljaütlemised annavad tõuke uute naljaseeriate või -kogumite tekkeks (nt on olemas mahukas internetisait, mis kogub verbaalseid ja mitteverbaalseid tsitaate neilt poliitikutelt, kes propageerisid nn IV Poola Vabariigi ideed), samas kui teised sellised lausungid jäävad vaid üksikuks poliitiliselt solvava avalduse märgiks.

Selliste ütluste (poliitiliste lendsõnade) tekstiline päritolu ja edasine saatus on ära toodud joonisel $\mathrm{nr} 1$ : 


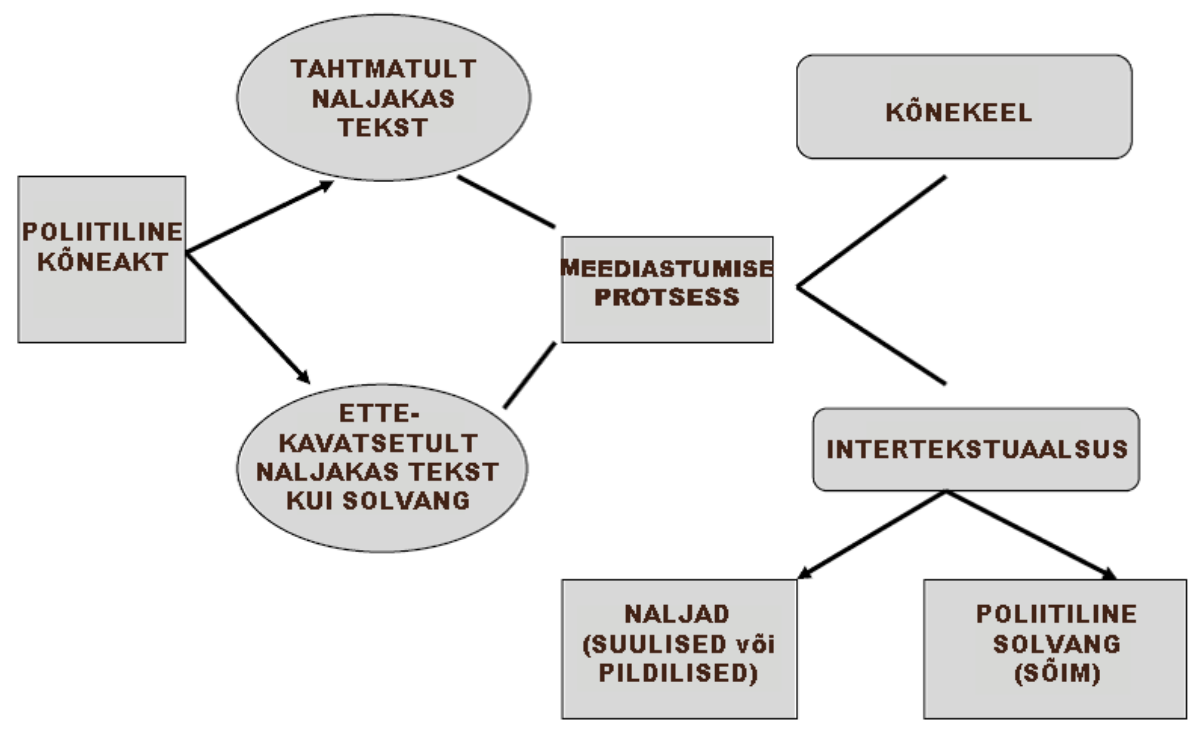

Joonis 1. Naljakate poliitiliste lendsõnade allikad ja tekstilised derivatsioonid.

Näib, et tänane avalik diskursus ei oleks terviklik ilma naljakate ütlusteta, kuigi nende vorm ei peegelda alati kirjeldatava poliitilise probleemi tõsidust. Ja kuigi selliste naljakate väljaütlemiste formaat võib olla solvav ja nendega rikutakse keelelis-stilistilisi suhtlusnorme e etiketti, võib neil olla mitmeid olulisi funktsioone paljudes suhtlusvaldkondades.

- Neist võivad saada märksõnad (diskursiivsed sümbolid), mida erinevad suhtluskogukonnad kasutavad oma ideoloogilise identiteedi indikaatorina (nt fraas mohäärkoalitsioon / mohäär - mõne keelekasutaja meelest on see humoorikas sõnamäng, kuid nende oponendid võtavad seda kui sildistamist, tähistamaks konservatiivsete gruppide toetajaid ja Tadeusz Rydzyki ringhäälingujaama ümber tekkinud kogukonda).

- Neid võivad parafraseerida ajakirjanikud (või anonüümsed keelekasutajad) eesmärgiga teha poliitilist satiiri, mõelda välja pealkirju või luua sisu infotainment-meelelahutussaadetele (nt saade "Szkło kontaktowe" poliitikute humoorikatest keelevääratustest TVN kanalil, vt Chłopicki 2009).

- Nad võivad omandada stabiilse tähenduse a) mingis teises diskursuses (nt tsitaadid / metonüümiad, mida kasutatakse alusainena tõlkides (po- 
pulaarseid) kultuuritekste, mis sisaldavad sisulisi viiteid poliitikale ja poliitilistele võimumängudele (vrd filmide "Shrek" või "Asterix" poolakeelseid tõlkeid)); b) tänapäevases kõnekeeles (nt zdrowie wasze w gardta nasze; plusy dodatnie i plusy ujemne; mordo ty moja!; [Teie terviseks läbi minu kõri; positiivsed ja negatiivsed plussid; ole minu semu!]); c) mõnikord isegi juriidilises ja poliitilises terminoloogias (nt falandyzacja (falandiseerima), gruba kreska [paks joon]).

\section{Tõlkinud Mall Leman}

\section{Kommentaarid}

1 "Mängulise genoloogia" (ludic genology) uurijate ja artiklite kohta vt Brzozowska 2010.

${ }^{2}$ Vrd kommentaare iroonia ja sarkasmi kui antiikaja avalikes kõnedes kasutatud kõnekujundite kohta.

3 Józef Piłsuski kõnede koomilise sisu kohta käivaid huvitavaid kommentaare loe Dawidziak-Kładoczna 2004.

${ }^{4}$ Üks kõige populaarsemaid poliitilise satiiri perioodikaväljaandeid oli sõjaeelne $M u c h a$ [Kärbes]; Poola Rahvavabariigi ajal jätkas selle visuaalse traditsiooniga Szpilki [Nööpnõelad], ajakiri, mida normeerisid poliitilised võimumehed; vrd Dubaniowska 2000 ja Kuźmiński artikkel aadressil http://www.reporterzy.info/224,prasa_satyryczna_i_ humorystyczna_w_XIX_i_XX_wieku.html.

5 Parimaks näiteks on siinkohal naljakad kommentaarid Teleexpressi (TVP 1) või Fakty (TVN) lõpuosas.

6 Vrd Brzozowska (2009a; 2009b) identiteetidest ja stereotüüpidest etnilistes naljades; vt ka Brzozowska 2012 ja Krikmann 2012.

7 Inkongruentsusest (ühitamatus) huumoritekstides ning selle kommunikatiivse nähtuse uurimiskontseptsioonist (viidetega Attardo, Raskini, Ruchi jt klassikalistele teooriatele) on teiste seas kirjutanud ka Kucharski (2010).

8 Vrd Brzozowska (2009a: 163) kommentaariga: "Mõned nalja elemendid võivad kergesti "saada tiivad", ja tihti nad esinevadki sellisel modifitseeritud kujul".

9 Neid nähtusi on käsitletud Poprawa 2010. 


\section{Kirjandus}

Anusiewicz, Janusz \& Anusiewicz, Bogdan \& Siciński, Bogdan (toim) 1994. Język a kultura t. 11. Język polityki a wspótczesna kultura polityczna [Keel ja kultuur 11. Keelepoliitika ja tänapäeva poliitiline kultuur]. Wrocław: Wydawnictwo Uniwersytetu Wrocławskiego.

Baran, Anneli 2012. Visual humour on the Internet. Laineste, Liisi \& Brzozowska, Dorota \& Chłopicki, Władysław (toim). Estonia and Poland. Creativity and tradition in cultural communication 1. Tartu: ELM Scholarly Press, lk 171-186.

Bauer, Zbigniew 2010. Dziennikarstwo wobec nowych mediów. Historia, teoria, praktyka [Ajakirjandus uues meedias. Ajalugu, teooria, praktika]. Kraków: Universitas.

Bralczyk, Jerzy 2001. O języku polskiej propagandy partyjnopaństwowej lat siedemdziesiątych $i$ osiemdziesiątych [Poliitika ja parteipropaganda keel 1970. ja 1980. aastatel]. Warszawa: TRIO.

Bralczyk, Jerzy \& Mosiołek-Kłosińska, Katarzyna (toim) 2001. Zmiany w publicznych zwyczajach językowych [Keelelise käitumise muutused]. Warszawa: Rada Języka Polskiego PAN.

Brzozowska, Dorota 2009a. Polish jokelore in the period of transition. Krikmann, Arvo \& Laineste, Liisi (toim). Permitted laughter. Socialist, post-socialist and never-socialist humour. Tartu: ELM Scholary Press, lk 127-170.

Brzozowska, Dorota 2009b. Polski dowcip etniczny [Poola etnilised naljad]. Opole: Wydawnictwo Uniwersytetu Opolskiego.

Brzozowska, Dorota 2009c. Polski dyskurs ludyczny i jego międzynarodowe konteksty [Poola huumoridiskursuse sõnavara ja selle kultuuriline kontekst]. Tekst $i$ dyskurs. Text und diskurs 2 , lk 149-162.

Chlebda, Wojciech 2005. Szkice o skrzydlatych stowach. Interpretacje lingwistyczne [Sketšid tiivustatud sõnadest. Lingvistilised interpretatsioonid]. Opole: Wydawnictwo Uniwersytetu Opolskiego.

Chłopicki, Władysław 2009. The "Szkło kontaktowe" show - A return to the old rationality? Krikmann, Arvo \& Laineste, Liisi (toim). Permitted laughter. Socialist, postsocialist and never-socialist humour. Tartu: ELM Scholary Press, lk 171-184.

Dawidziak-Kładoczna, Małgorzata 2004. “Cherlacy z sercem oziębłym”. O języku pism $i$ mów Józefa Piłsudkiego [Józef Piłsudski kirjade ja kõnede keelest]. Prace językoznawcze 7. Łask: Oficyna Wydawnicza Leksem.

Davies, Christie 2009. Post-socialist, socialist and never-socialist jokes and humour: Continuities and contrasts. Krikmann, Arvo \& Laineste, Liisi (toim). Permitted laughter. Socialist, post-socialist and never-socialist humour. Tartu: ELM Scholary Press, lk 17-40.

Dytman-Stasieńko, Agnieszka 2006. Święto zawłaszczonych znaczeń. 1 Maja w PRL. Ideologia. Rytuat. Język [Pühale omistatud tähendustest. 1. mai PRVs. Ideoloogia, rituaal ja keel]. Wrocław: Wydawnictwo Naukowe DSWE TWP. 
Głowiński, Michał 1992. Nowomowa po polsku [Poola uuskeel]. Warszawa: Wydawnictwo PEN.

Godzic, Wiesław 2004. Telewizja i jej gatunki po "Wielkim Bracie” [Televisioon ja selle žanrid pärast "suurt venda"]. Kraków: Universitas.

Habrajska, Grażyna 1994. Wykorzystywanie ironii do walki politycznej [Iroonia funktsioonid poliitilises võitluses]. Anusiewicz, Janusz \& Siciński, Bogdan (toim). Język a kultura 11. Język polityki a wspótczesna kultura polityczna [Keel ja Kultuur 11. Poliitika keel ja tänapäeva poliitiline kultuur]. Wrocław: Wydawnictwo Uniwersytetu Wrocławskiego, lk 57-68.

Kamińska-Szmaj, Irena 2001. Stowa na wolności. Język polityki po 1989 roku [Sõnavabadus. Keelepoliitika pärast 1989. aastat]. Wrocław: Europa.

Kamińska-Szmaj, Irena 2007. Agresja językowa w życiu publicznym. Leksykon inwektyw politycznych 1918-2000 [Keeleline agressioon avalikkuses. Poliitilise sõimu leksikon 1918-2000]. Wrocław: Wydawnictwo Uniwersytetu Wrocławskiego.

Kita, Małgorzata 2000. O "złotych myślach" osób publicznych [Avaliku elu tegelaste "kuldsed sõnad"]. Brzozowska, Dorota \& Gajda, Stanisław (toim). Świat humoru [Huumorimaailm]. Opole: Wydawnictwo Uniwersytetu Opolskiego, lk 261-270.

Kloch, Zbigniew 2006. Odmiany dyskursu. Semiotyka życia publicznego w Polsce po 1989 roku [Diskursuse modifikatsioonid. Poola avaliku elu semiootika pärast 1989. aastat]. Wrocław: Wydawnictwo Uniwersytetu Wrocławskiego.

Korolko, Mirosław 1996. Sztuka retoryki [Kõnekunst]. Warszawa: PWN.

Krikmann, Arvo 2012. Estonian three nation jokes (1964-2012). Laineste, Liisi \& Brzozowska, Dorota \& Chłopicki, Władysław (toim). Estonia and Poland. Creativity and tradition in cultural communication 1. Tartu: ELM Scholarly Press, lk 7-20.

Kucharski, Andrzej 2009. Struktura i treść jako wyznaczniki komizmu tekstów humorystycznych [Struktuur ja sisu kui naljade koomilisuse määrajad]. Lublin: Wydawnictwo UMCS.

Kudra, Barbara 2001. Kreatywność leksykalna w dyskursie politycznym polskiej prasy lat osiemdziesiątych i dziewięćdziesiątych [Leksikaalne loovus Poola 1980. ja 1990. aastate ajakirjanduse poliitilises diskursuses]. Łódź: Wydawnictwo Uniwersytetu Łódzkiego.

Lew, Robert 2000. Dowcip językowy w świetle najnowszych językoznawczych teorii humoru [Sajandivahetuse naljad Poolas]. Dorota Brzozowska \& Stanisław Gajda (toim). Świat humoru [Huumorimaailm]. Opole: Wydawnictwo Uniwersytetu Opolskiego, lk 117-125.

Magdoń, Stanisław 1995. Duch zabawy w mediach [Lõbususe vaim meedias]. Zeszyty Prasoznawcze 3-4, lk 7-16.

Olczyk, Tomasz 2010. Politorozrywka i popperswazja. Reklama telewizyjna w polskich kampaniach wyborczych XXI wieku [Popmeelelahutus ja veenmine. Poola 21. sajandi valimiskampaaniate telereklaamid]. Warszawa: Wydawnictwa Akademickie i Profesjonalne. 
Ożóg, Kazimierz 2004. Język w stużbie polityki [Keel poliitika teenistuses]. Rzeszów: Wydawnictwo Uniwersytetu Rzeszowskiego.

Piekot, Tomasz 2012. Pictorial representation of idioms in Internet humour. Laineste, Liisi \& Brzozowska, Dorota \& Chłopicki, Władysław (toim). Estonia and Poland. Creativity and tradition in cultural communication 1. Tartu: ELM Scholarly Press, lk 187-204.

Poprawa, Marcin 2009. Telewizyjne debaty polityków jako przykład dyskursu publicznego [Teledebatid avaliku diskursuse näitena]. Kraków: Universitas.

Poprawa, Marcin 2010. Intertekstualność dyskursu publicznego - znak wspólnot komunikacyjnych czy konfliktów [Avaliku arutelu intertekstuaalsus - suhtluse või konfliktide märk]. Mazur, Jan \& Małyska, Agnieszka \& Sobstyl, Katarzyna (toim). Intertekstualność we wspótczesnej komunikacji językowej [Intertekstuaalsus tänapäeva lingvistilises suhtluses]. Lublin: Wydawnictwo UMSC, lk 111-123.

Rebane, Martin 2012. Some aspects of telling political jokes in the Soviet Estonia. Laineste, Liisi \& Brzozowska, Dorota \& Chłopicki, Władysław (toim). Estonia and Poland. Creativity and tradition in cultural communication 1. Tartu: ELM Scholarly Press, $\mathrm{lk}$ 111-116.

STL = Sławiński, Janusz \& Głowiński, Michał \& Kostkiewiczowa, Teresa (toim) 1998. Stownik terminów literackich [Kirjandusterminite sõnaraamat]. Wrocław: Ossolineum.

Szkudlarek-Śmiechowicz, Ewa 2011. Tekst w radiowej i telewizyjnej debacie politycznej [Tekst raadio ja televisiooni poliitilistes debattides]. Łódź: Wydawnictwo Uniwersytetu Łódzkiego.

Van Dijk, Teun A. 2001. Badania nad dyskursem [Diskursuseuuringud]. van Dijk, Teun A. (toim). Dyskurs jako struktura i proces [Diskursus kui struktuur ja protsess]. Grochowski, Grzegorz (tlk). Warszawa: PWN, lk 9-44.

Wojtak, Maria, 2010. Gtosy z teraźniejszości. O języku wspótczesnej prasy polskiej [Tänapäeva hääled. Poola nüüdispressi keelest]. Lublin: Wydawnictwo WSPA (www. ipn.gov.pl - 27. november 2012). 


\section{Summary}

\section{Polish political humour}

\section{Marcin Poprawa}

Keywords: Polish political humour, intertextuality, winged words, political discourse, language of politics

This article is a survey of the most important communicative phenomena in the contemporary Polish political humour. It is also an attempt to describe political humour from a theoretical point of view and to compare it with political jokes from a period of the Polish People's Republic (PRL). This article mainly describes amusing statements of contemporary politicians that were primarily used as the means of a political polemic, and secondarily after having been popularised by journalists (due to their comic content), achieved a status of "winged words" and appeared in various intertextual variants of the public and colloquial discourse. 